\title{
Common variants in the $C R P$ gene are associated with serum $C$-reactive protein levels and body mass index in healthy individuals in Mexico
}

\author{
E. Flores-Alfaro ${ }^{1}$, G. Fernández-Tilapa ${ }^{1}$, E. Salazar-Martínez ${ }^{2,3}$, \\ M. Cruz ${ }^{4}$, B. Illades-Aguiar ${ }^{1}$ and I. Parra-Rojas ${ }^{1}$ \\ ${ }^{1}$ Laboratorio de Enfermedades Crónico Degenerativas, \\ Unidad Académica de Ciencias Químico Biológicas, \\ Universidad Autónoma de Guerrero, Chilpancingo, México \\ ${ }^{2}$ Centro de Investigación en Salud Poblacional, \\ Instituto Nacional de Salud Pública, Cuernavaca, México \\ ${ }^{3}$ Instituto Mexicano de Seguridad Social, Cuernavaca, México \\ ${ }^{4}$ Unidad de Investigación Médica en Bioquímica, Hospital de Especialidades, \\ Centro Médico Nacional "Siglo XXI", Instituto Mexicano del Seguro Social, \\ Cuernavaca, México
}

Corresponding author: E. Flores-Alfaro

E-mail: efloresa_2@hotmail.com

Genet. Mol. Res. 11 (3): 2258-2267 (2012)

Received August 17, 2011

Accepted January 29, 2012

Published May 14, 2012

DOI http://dx.doi.org/10.4238/2012.May.14.5

\begin{abstract}
Variants in the $\mathrm{C}$-reactive protein $(C R P)$ gene have been found to be associated with various phenotypic traits. We evaluated the effect of four SNPs in the CRP gene on serum levels of protein and body mass index (BMI) in 150 unrelated Mexican subjects from 18 to 25 years old, without hypertension, non-overweight, and without inflammatory diseases, non-smoking and non-consumers of alcohol. Subjects were measured for BMI, waist circumference, blood pressure, and serum glucose and triglycerides. The identification of SNPs was
\end{abstract}


performed by PCR-RFLP. Three of the four SNPs were associated with variation in serum levels of CRP, increased in TT (rs1130864) and GG (rs2794521) genotypes, and decreased in the AA genotype of rs1205. The TT genotype was associated with a significant increase in BMI $(\beta$ $\left.=1.1 \mathrm{~kg} / \mathrm{m}^{2}, \mathrm{P}=0.04\right)$. Two haplotypes were significantly associated with increased serum levels of CRP, but not with BMI. We conclude that variation in the $C R P$ gene affects serum protein levels.

Key words: $\mathrm{C}$-reactive protein; $C R P$ gene; Body mass index; Haplotypes

\section{INTRODUCTION}

Various biological and genetic markers, such as proinflammatory cytokines and C-reactive protein (CRP), secreted by the liver in response to the stimulation of interleukins 1 and 6 and tumor necrosis factor alpha, have been proposed for the prediction and early assessment of cardiovascular disease (CVD) risk (Black et al., 2004). Elevated blood levels of CRP have been associated with atherosclerosis (Momiyama et al., 2010), unstable angina (Rizzello et al., 2007), diabetes (Shankar and Li, 2008), metabolic syndrome (Lai et al., 2010), insulin resistance (Gelaye et al., 2010), and obesity (Wee et al., 2008). Prospective studies have shown that increased blood CRP levels are associated with a greater risk of ischemic heart and cerebrovascular diseases (Sabatine et al., 2007; Oudi et al., 2010).

CRP mediates phagocytosis of low-density lipoprotein by macrophages, induces apoptosis of endothelial cells, inhibits angiogenesis, and increases activation of nuclear factor kappa $\beta$. CRP is also involved in endothelial activation and the survival and differentiation of endothelial progenitor cells. The capability of CRP to inhibit progenitor endothelial cells may be an important mechanism in the inhibition of angiogenesis in chronic ischemia. The concentration of CRP may be an indicator of endothelial dysfunction as well as a mediator of insulin resistance and arterial injury (Sanchez-Recalde and Carlos, 2001). Several studies have reported that variants in the $C R P$ gene are associated with variations in blood levels of CRP in cardiovascular and other diseases such as diabetes, microangiopathic stroke, metabolic syndrome, and hypertension (Brull et al., 2003; Chen et al., 2005; Szalai et al., 2005; Lange et al., 2006; Komurcu-Bayrak et al., 2009; Hsu et al., 2010; Kuhlenbaeumer et al., 2010).

The majority of studies examining the relationship between various $C R P$ polymorphisms and serum protein or the risk of CVD have been conducted in white populations. Only one study has reported an association of the polymorphism rs1130864 in the CRP gene with increased serum levels of CRP in adolescents of western Mexico (Guadalajara, Jalisco) with Spanish high genetic component (INAFED, 2005; Mendoza-Carrera et al., 2010). However, these results may vary owing to the genetic diversity of the Mexican population. Previous studies in a population of the State of Guerrero (southwest Mexico) have shown a higher percentage of Native American ancestry (66\%; Silva-Zolezzi et al., 2009). Another study in Mexico City showed 65\% Native American ancestry (Martínez-Marignac et al., 2007). This value was modified when the study was conducted in individuals from the northwest, in which a 56\% Amerindian component was determined (Martinez-Fierro et al., 2009). In this context, our interest was to evaluate the relationship between CRP variants and blood levels of CRP and body mass index (BMI) in subjects stratified by risk of coronary heart disease (CHD) in Guerrero State, Mexico. 


\section{PATIENTS AND METHODS}

\section{Study type and subjects}

A genetic association study was conducted in 150 healthy, genetically unrelated individuals aged 18 to 25 years without overweight or hypertension. All participants were born in Guerrero State, Mexico, as were their parents and grandparents. Individuals who were overweight or obese, smoked, drank alcohol, had a diagnosis of CVD, presented with evidence of infectious disease within the previous 15 days, or had received any treatment that could influence the biochemical parameters were excluded from the study. The subjects received written and oral information before giving their consent to participate. The study was approved by the Ethics Committee of the University of Guerrero. Each of the participants answered a questionnaire to provide socio-demographic data, family history, and history of diseases. Weight $(\mathrm{kg})$, height $(\mathrm{m})$, waist circumference $(\mathrm{cm})$, and blood pressure $(\mathrm{mmHg})$ were also measured. A fasting blood sample was obtained from each subject.

\section{Laboratory measurements}

Serum glucose and triglyceride levels were obtained using routine biochemical analysis. High-sensitivity CRP levels were measured via immunonephelometry with an automated BN-100 system (Dade Berhing). The intra- and interassay coefficients of variation of CRP were $<4.2$ and $<5.5 \%$, respectively, and the analytical sensitivity was 0.175 $\mathrm{mg} / \mathrm{L}$. To evaluate the risk of CHD, we used cut points for CRP levels at low risk $(<1.0$ $\mathrm{mg} / \mathrm{L})$, average risk $(1.0$ to $3.0 \mathrm{mg} / \mathrm{L})$, and high risk $(>3.0 \mathrm{mg} / \mathrm{L})$ based on the criteria of the Centers for Disease Control and Prevention and the American Heart Association (Pearson et al., 2003).

\section{Genotyping}

DNA was extracted from peripheral blood leukocytes using a salting-out procedure. Gene fragments containing the $+1444 \mathrm{C}>\mathrm{T}$ ( $\mathrm{rs} 1130864),+1846 \mathrm{G}>\mathrm{A}(\mathrm{rs} 1205),-717$ $\mathrm{A}>\mathrm{G}(\mathrm{rs} 2794521)$, and $-409 \mathrm{G}>\mathrm{A}$ (rs3093062) variant sites in CRP were amplified using polymerase chain reaction (PCR). The amplification products were digested with the appropriate restriction enzymes under the conditions recommended by the manufacturers (New England Biolabs, USA) according to protocols described elsewhere (Brull et al., 2003; Russell et al., 2004; Chen et al., 2005; Szalai et al., 2005). The digested fragments were then separated using electrophoresis on $4 \%$ agarose gels, followed by ethidium bromide staining and visualization under ultraviolet light. To improve genotyping accuracy, we used samples with known genotypes in each batch as positive controls to evaluate the completeness of the PCR product. The primers and restriction enzymes used are described in Table 1.

\section{Statistical analyses}

Comparisons between genders and risk of CHD by CRP level were performed using 
the chi-square test, the Student $t$-test, the Mann-Whitney U-test, or analysis of variance. The Spearman correlation coefficient was used to assess the relationship between CRP and other variables. Departures from Hardy-Weinberg equilibrium were verified using the chi-square test with one degree of freedom. The effects of the various genotypes and haplotypes of the $C R P$ gene on the concentration of CRP and BMI were evaluated with multiple linear regression models. Statistical analyses were performed using STATA (v.10.1) and $\mathrm{P}<0.05$ was reported as statistically significant. Haplotypes were constructed using the genetic data analysis program SNPStats (http://bioinfo.iconcologia.net/SNPstats).

Table 1. Primers and restriction enzymes used.
\begin{tabular}{llll}
\hline SNP & \multicolumn{2}{c}{ Primers } & \multirow{2}{*}{ Enzyme } \\
\cline { 2 - 4 } & Forward & Reverse & \\
\hline rs1130864 & 5'-AGCTCGTTAACTATGCTGGGGCA-3' & 5'-CTTCTCAGCTCTTGCCTTATGAGT-3' & HpyCH $_{4}$ III \\
rs1205 & 5'-GGAGTGAGACATCTTCTTG-3' & 5'-CTTATAGACCTGGGCAGT-3' & HpyCH $_{4}$ III \\
rs2794521 & 5'-GCCGTCATTTAGTGCCAAC-3' & 5'-ATGCTCCTCCCAGAGCCATGG-3' & Bstu1 \\
rs3093062 & 5'-TTTGGGCTAAGTAGGTGTTG-3' & 5'-AGGGCTCCACTTTGGCTATC-3' & ApalI \\
\hline
\end{tabular}

$\mathrm{SNP}=$ single nucleotide polymorphism.

\section{RESULTS}

\section{Clinical and demographic characteristics}

The average age of subjects was 20.5 years, and $65.3 \%$ were women. The average BMI, waist circumference, systolic and diastolic blood pressures, and serum triglycerides were higher in men. The serum CRP level was higher in women $(0.70$ vs $0.51 \mathrm{mg} / \mathrm{L})$. Of the participants, $69.4 \%$ reported having an ancestral origin (grandparents and parents) in the central area of Guerrero State, $7.3 \%$ in the north, 5.3\% in the mountains, and smaller proportions in other regions of the state. The largest proportion of women reported having a family history of diabetes and CVD (Table 2). CRP was positively correlated with BMI $(r=0.22, \mathrm{P}=0.026$; data not shown). This relationship is shown in Table 3 , which shows a significant trend in average BMI increasing with increasing CRP levels stratified according CHD risk.

\section{Genotype and allele frequencies}

Individuals carrying the TT genotype for SNP rs 1130864 included $14.7 \%$ of subjects; the AA genotype of rs 1205 included $22.7 \%$, and the GG genotype of rs 2794521 composed $2 \%$. The SNP rs3093062 AA genotype was not observed in the population analyzed. None of the polymorphisms showed deviation from Hardy-Weinberg equilibrium. Serum CRP levels were increased through the genotypes of rs1130864 and rs2794521 polymorphisms, from the highest to the lowest genotype frequency. Trends were observed in the frequencies of risk genotypes, TT and GG, across the CRP risk strata (Table 4).

\section{Effect of variation in the $C R P$ gene on CRP levels and BMI}

We found an average increase of $0.6 \mathrm{mg} / \mathrm{L}$ in serum CRP in individuals carrying 
the TT variant of SNP rs1130864 compared with genotype CC, and the GG rs2794521 variant displayed an increase of $1.4 \mathrm{mg} / \mathrm{L}$ compared with the AA genotype. Conversely, in carriers of the rs 1205 AA variant, serum CRP was decreased by $0.5 \mathrm{mg} / \mathrm{L}$. Differences were adjusted for gender, BMI, region of origin, and family history of CVD (Table 5). Compared with individuals carrying the CC genotype, only the TT genotype of rs1130864 polymorphism had an effect on the average increase in BMI $\left(\beta\right.$ coefficient $=1.1 \mathrm{~kg} / \mathrm{m}^{2}$; $95 \%$ confidence interval $=0.1-2.1 ; \mathrm{P}=0.04)$ in a model adjusted for gender, region of origin, and family history of CVD (data not shown). This effect was not seen with any other clinical variable.

\begin{tabular}{|c|c|c|c|c|}
\hline Characteristic & $\begin{array}{c}\text { Total } \\
\mathrm{N}=150\end{array}$ & $\begin{aligned} & \text { Men } \\
\mathrm{N}= & 52(34.7)\end{aligned}$ & $\begin{array}{c}\text { Women } \\
\mathrm{N}=98(65.3)\end{array}$ & P value \\
\hline Age (years) & $20.5 \pm 1.7$ & $20.6 \pm 1.6$ & $20.5 \pm 1.7$ & $0.713^{\dagger}$ \\
\hline BMI $\left(\mathrm{kg} / \mathrm{m}^{2}\right)$ & $21.5 \pm 2.1$ & $22.1 \pm 1.9$ & $21.1 \pm 2.2$ & $0.008^{\dagger}$ \\
\hline Waist circumference $(\mathrm{cm})$ & $75.5 \pm 7.4$ & $80 \pm 7.0$ & $73.1 \pm 6.5$ & $<0.001^{\dagger}$ \\
\hline Systolic BP (mmHg) & $103.8 \pm 11.5$ & $109.9 \pm 10.3$ & $100.6 \pm 10.8$ & $<0.001^{\dagger}$ \\
\hline Diastolic BP (mmHg) & $66.6 \pm 8.1$ & $68.7 \pm 9.0$ & $65.6 \pm 7.4$ & $0.025^{\dagger}$ \\
\hline \multicolumn{5}{|c|}{ Region of origin [Guerrero State, N (\%)] } \\
\hline Center & $104(69.4)$ & $37(71.1)$ & $67(68.4)$ & \multirow[t]{6}{*}{$0.535^{+}$} \\
\hline North & $11(7.3)$ & $6(11.5)$ & $5(5.1)$ & \\
\hline Mountain & $8(5.3)$ & $2(3.9)$ & $6(6.1)$ & \\
\hline Costa Grande & $8(5.3)$ & $2(3.9)$ & $6(6.1)$ & \\
\hline Other & $11(7.4)$ & $4(7.7)$ & $7(7.2)$ & \\
\hline Not reported & $8(5.3)$ & $1(1.9)$ & $7(7.1)$ & \\
\hline FH of diabetes (yes), $\mathrm{N}(\%)$ & $91(60.7)$ & $25(48.1)$ & $66(67.3)$ & $0.021^{+}$ \\
\hline FH of CVD (yes), N (\%) & $55(36.7)$ & $13(25.0)$ & $42(42.9)$ & $0.031^{+}$ \\
\hline Exercise (yes), N (\%) & $93(62.0)$ & $44(84.6)$ & $49(50.0)$ & $<0.001^{+}$ \\
\hline Glucose (mg/dL) & $87.9 \pm 12.1$ & $88.8 \pm 10.7$ & $87.4 \pm 12.9$ & $0.582^{\dagger}$ \\
\hline Triglycerides $(\mathrm{mg} / \mathrm{dL})^{*}$ & $100.6(5.5)$ & $116.8(11.7)$ & $92.9(5.5)$ & $0.002^{\S}$ \\
\hline HsCRP $(\mathrm{mg} / \mathrm{L})^{*}$ & $0.63(0.08)$ & $0.51(0.09)$ & $0.70(0.11)$ & $0.053^{\S}$ \\
\hline \multicolumn{5}{|l|}{ HsCRP from CVD risk, $\mathrm{N}(\%)$} \\
\hline$<1 \mathrm{mg} / \mathrm{L}$ & $98(65.4)$ & $40(76.9)$ & $58(59.2)$ & \multirow[t]{3}{*}{$0.075^{4}$} \\
\hline $1-3 \mathrm{mg} / \mathrm{L}$ & $44(29.3)$ & $11(21.2)$ & $33(33.7)$ & \\
\hline$>3 \mathrm{mg} / \mathrm{L}$ & $8(5.3)$ & $1(1.9)$ & $7(7.1)$ & \\
\hline
\end{tabular}

Data are reported as means \pm standard deviation or $\mathrm{N}(\%) .{ }^{*}$ Geometric mean (SE); ${ }^{\dagger}$ Student $t$-test, $\chi^{2}$ test; ${ }^{\star *,}$ MannWhitney test; $\mathrm{BMI}=$ body mass index; $\mathrm{BP}=$ blood pressure; $\mathrm{FH}=$ family history; $\mathrm{CVD}=$ cardiovascular disease; $\mathrm{HsCRP}=$ high sensitivity C-reactive protein.

Table 3. Factors and their relationship with cardiovascular disease (CVD) risk C-reactive protein (CRP).

\begin{tabular}{|c|c|c|c|c|}
\hline \multirow[t]{2}{*}{ Factor } & \multicolumn{4}{|c|}{$\mathrm{CRP}(\mathrm{mg} / \mathrm{L})$} \\
\hline & Low $(<1)$ & Average (1-3) & $\operatorname{High}(>3)$ & $P$ value \\
\hline \multicolumn{5}{|l|}{ Gender, N (\%) } \\
\hline Male & $40(40.8)$ & $11(25.0)$ & $1(12.5)$ & $0.082^{\dagger}$ \\
\hline Female & $58(59.2)$ & $33(75.0)$ & $7(87.5)$ & \\
\hline BMI $\left(\mathrm{kg} / \mathrm{m}^{2}\right)$ & $21.1 \pm 2.1$ & $22.0 \pm 2.0$ & $22.2 \pm 2.2$ & $0.040^{*}$ \\
\hline Waist circumference $(\mathrm{cm})$ & $74.7 \pm 7.7$ & $77.1 \pm 7.0$ & $76.3 \pm 5.5$ & $0.200^{\ddagger}$ \\
\hline Systolic BP (mmHg) & $103 \pm 12.0$ & $104 \pm 11.0$ & $104 \pm 9.2$ & $0.770^{*}$ \\
\hline Diastolic BP (mmHg) & $66 \pm 7.6$ & $68 \pm 9.1$ & $66 \pm 7.4$ & $0.275^{+}$ \\
\hline FH of diabetes (yes), N (\%) & $59(60.2)$ & $26(59.1)$ & $6(75.0)$ & $0.746^{\dagger}$ \\
\hline FH of CVD (yes), N (\%) & $34(34.7)$ & $17(38.6)$ & $4(50.0)$ & $0.616^{\dagger}$ \\
\hline Exercise (yes), N (\%) & $59(60.2)$ & $30(68.2)$ & $4(50.0)$ & $0.517^{\dagger}$ \\
\hline
\end{tabular}

${ }^{\dagger}$ Fisher exact test, ${ }^{\ddagger}$ Analysis of variance. For abbreviations, see legend to Table 2. 
Table 4. C-reactive protein (CRP) levels according to genotypes and alleles of the $C R P$ gene polymorphisms.

\begin{tabular}{|c|c|c|c|c|c|c|}
\hline \multirow[t]{2}{*}{ Polymorphism } & \multirow[t]{2}{*}{ Frequencies, N (\%) } & \multirow[t]{2}{*}{ Geometric mean CRP (mg/L) } & \multicolumn{4}{|c|}{ CRP for CVD risk, $\mathrm{N}(\%)$} \\
\hline & & & Low $(<1)$ & Average (1-3) & $\operatorname{High}(>3)$ & $P$ \\
\hline \multicolumn{7}{|l|}{ rs1130864 } \\
\hline $\mathrm{CC}$ & $54(36.0)$ & $0.5(0.10)$ & $43(43.9)$ & $10(22.7)$ & $1(12.5)$ & 0.022 \\
\hline $\mathrm{CT}$ & $74(49.3)$ & $0.7(0.12)$ & 45 (45.9) & $25(56.8)$ & $4(50.0)$ & \\
\hline TT & $22(14.7)$ & $1.0(0.24)$ & $10(10.2)$ & $9(20.5)$ & $3(37.5)$ & \\
\hline $\mathrm{C}$ & $182(0.61)$ & $0.6(0.11)$ & $131(0.67)$ & $45(0.51)$ & $6(0.38)$ & \\
\hline $\mathrm{T}$ & $118(0.39)$ & $0.8(0.18)$ & $65(0.33)$ & $43(0.49)$ & $10(0.62)$ & \\
\hline HWE: $\chi^{2}(\mathrm{P})$ & $0.17(0.68)$ & & & & & \\
\hline \multicolumn{7}{|l|}{ rs 1205} \\
\hline GG & $45(30.0)$ & $0.8(0.20)$ & $24(24.5)$ & $15(34.1)$ & $6(75.0)$ & 0.020 \\
\hline GA & $71(47.3)$ & $0.6(0.10)$ & $46(46.9)$ & $23(52.3)$ & $2(25.0)$ & \\
\hline AA & $34(22.7)$ & $0.4(0.09)$ & $28(28.6)$ & $6(13.6)$ & 0 & \\
\hline G & $161(0.54)$ & $0.7(0.15)$ & $94(0.48)$ & $53(0.60)$ & $14(0.88)$ & \\
\hline A & $139(0.46)$ & $0.5(0.09)$ & $102(0.52)$ & $35(0.40)$ & $2(0.12)$ & \\
\hline HWE: $\chi^{2}(\mathrm{P})$ & $0.35(0.55)$ & & & & & \\
\hline \multicolumn{7}{|l|}{ rs2794521 } \\
\hline AA & $115(76.7)$ & $0.6(0.09)$ & $81(82.7)$ & $28(63.6)$ & $6(75.0)$ & 0.012 \\
\hline $\mathrm{AG}$ & $32(21.3)$ & $0.7(0.18)$ & $17(17.3)$ & $14(31.8)$ & $1(12.5)$ & \\
\hline GG & $3(2.0)$ & $2.2(0.92)$ & 0 & $2(4.6)$ & $1(12.5$ & \\
\hline $\mathrm{A}$ & $262(0.87)$ & $0.6(0.13)$ & $179(0.91)$ & $70(0.80)$ & $13(0.81)$ & \\
\hline G & $38(0.13)$ & $1.5(0.55)$ & $17(0.09)$ & $18(0.20)$ & $3(0.19)$ & \\
\hline HWE: $\chi^{2}(\mathrm{P})$ & $0.19(0.66)$ & & & & & \\
\hline \multicolumn{7}{|l|}{ rs 3093062} \\
\hline GG & 148 (98.7) & $0.6(0.08)$ & $97(99.0)$ & $43(97.7)$ & $8(100)$ & 0.575 \\
\hline GA & $2(1.3)$ & $0.9(0.68)$ & $1(1.0)$ & $1(2.3)$ & 0 & \\
\hline G & $298(0.99)$ & $0.8(0.38)$ & $195(0.99)$ & $87(0.99)$ & $16(1.00)$ & \\
\hline A & $2(0.01)$ & $0.9(0.68)$ & $1(0.01)$ & $1(0.01)$ & 0 & \\
\hline HWE: $\chi^{2}(\mathrm{P})$ & $0.01(0.93)$ & & & & & \\
\hline
\end{tabular}

$\mathrm{HWE}=$ Hardy-Weinberg equilibrium. $\mathrm{CVD}=$ cardiovascular disease.

Table 5. Effect of genotypes on serum C-reactive protein levels.

\begin{tabular}{lcccccc}
\hline SNP & Genotype & $\beta(95 \% \mathrm{CI})^{\mathrm{a}}$ & P value & $\beta(95 \% \text { CI })^{\mathrm{b}}$ & $\mathrm{R}^{2}$ & P value \\
\hline rs1130864 & CC & Ref. & & Ref. & & \\
& CT & $0.3(-0.03,0.6)$ & 0.083 & $0.3(0.01,0.6)$ & 0.16 & 0.048 \\
& TT & $0.7(0.2,1.2)$ & 0.003 & $0.6(0.1,1.0)$ & & 0.011 \\
rs1205 & CT+TT & $0.4(0.1,0.7)$ & 0.017 & $0.4(0.1,0.7)$ & & 0.013 \\
& GG & Ref. & & Ref. & & \\
& GA & $-0.2(-0.6,0.1)$ & 0.189 & $-0.3(-0.6,0.06)$ & 0.15 & 0.109 \\
& AA & $-0.6(-1.0,-0.1)$ & 0.002 & $-0.5(-0.9,-0.1)$ & & 0.010 \\
rs2794521 & GA+AA & $-0.3(-0.7,-0.01)$ & 0.044 & $-0.4(-0.7,-0.04)$ & & 0.026 \\
& AA & Ref. & & Ref. & & \\
& AG & $0.2(-0.2,0.6)$ & 0.320 & $0.3(-0.1,0.6)$ & 0.16 & 0.151 \\
& GG & $1.3(0.3,2.4)$ & 0.016 & $1.4(0.3,2.4)$ & & 0.010 \\
rs3093062 & AG+GG & $0.3(-0.1,0.6)$ & 0.120 & $0.3(0.01,0.7)$ & & 0.047 \\
& GG & Ref. & & Ref. & & \\
& GA & $0.4(-1.0,1.7)$ & 0.576 & $0.2(-1.1,1.5)$ & 0.11 & 0.795 \\
\hline
\end{tabular}

$\mathrm{SNP}=$ single nucleotide polymorphism; $\beta=$ regression coefficient; $95 \% \mathrm{CI}=$ confidence interval. ${ }^{\text {a Unadjusted; }}$ ${ }^{\mathrm{b}}$ Adjusted by gender, body mass index, region of origin, and family history of cardiovascular disease.

\section{Relationship of $C R P$ gene haplotypes and CRP concentration}

Haplotypes 3 (TGAG) and 5 (CGGG) of $C R P$ had significant effects on the average increase in concentration of CRP $(\beta=0.6 \mathrm{mg} / \mathrm{L} ; 95 \%$ confidence interval $=0.3-0.9 ; \mathrm{P}<0.001)$ 
compared to the most frequent haplotype (Table 6). We did not observe the same effect on the increase in BMI.

\begin{tabular}{|c|c|c|c|c|c|c|c|}
\hline \multirow[t]{2}{*}{ Haplotype } & \multicolumn{5}{|c|}{ SNP } & \multicolumn{2}{|c|}{$\mathrm{CRP}(\mathrm{mg} / \mathrm{L})$} \\
\hline & rs1130864 & rs 1205 & rs2794521 & rs3093062 & Frequency & $\beta(95 \% \mathrm{CI})^{\mathrm{a}}$ & P value \\
\hline 1 & $\mathrm{C}$ & A & A & G & 0.285 & Reference & \\
\hline 2 & $\mathrm{C}$ & G & A & G & 0.225 & $0.1(-0.3,0.4)$ & 0.630 \\
\hline 3 & $\mathrm{~T}$ & G & A & G & 0.192 & $0.6(0.3,0.9)$ & $<0.001$ \\
\hline 4 & $\mathrm{~T}$ & A & A & G & 0.165 & $0.2(-0.2,0.6)$ & 0.280 \\
\hline 5 & $\mathrm{C}$ & G & G & G & 0.087 & $0.9(0.3,1.2)$ & 0.001 \\
\hline 6 & $\mathrm{~T}$ & G & G & G & 0.026 & $-0.04(-0.7,0.7)$ & 0.910 \\
\hline Rare & & & & & 0.020 & $0.6(-0.3,1.4)$ & 0.210 \\
\hline
\end{tabular}

$\mathrm{SNP}=$ single nucleotide polymorphism; $95 \% \mathrm{CI}=$ confidence interval. ${ }^{\mathrm{a}}$ Adjusted by gender, body mass index, region of origin, and family history of cardiovascular disease.

\section{DISCUSSION}

Increased serum CRP levels have been reported in subjects with obesity, metabolic syndrome, and type 2 diabetes (T2D), indicating that these individuals present a state of subclinical, low-grade inflammation that promotes the development of atherosclerosis mediated by a process of endothelial dysfunction, increasing the risk of ischemic heart disease (Wee et al., 2008; Hu et al., 2009). Serum CRP levels vary widely among individuals and, in the absence of disease, are influenced by socio-demographic factors, lifestyle, and significantly, gender, and obesity (Flores-Alfaro et al., 2008; Wee et al., 2008; Tsai and Tsai, 2010). It has been shown that variation in CRP influences the concentration of protein (Carlson et al., 2005).

We designed a genetic association study to assess the effect of $4 C R P$ polymorphisms on CRP levels and BMI, minimizing the influence of factors that modify CRP, such as overweight and obesity, disease involving inflammation, smoking, and alcohol consumption. We found that increased BMI, elevated serum CRP levels, and average protein concentration are higher in women than in men. These results indicate an indirect effect of the increase in adipose tissue on the secretion of pro-inflammatory cytokines (interleukins 1 and 6, and tumor necrosis factor $\alpha$ ), which regulate the synthesis and secretion of CRP (Blake and Ridker, 2001).

The minor allele frequencies reported for the rs1130864 SNP (T) in different populations worldwide vary from 13 to $34.6 \%$. The genotype frequencies of SNPs rs 1130864 and rs3093062 revealed in this study did not differ significantly from those reported in other studies (Kim et al., 2008; Kolz et al., 2008; Almeida et al., 2009; Grammer et al., 2009; Schumacher et al., 2009; Mendoza-Carrera et al., 2010). Differences did arise, however, in the frequencies of SNP rs1130864 found in this study and those from a study conducted in Africa (Israelsson et al., 2009), which may be due to genetic differences between subjects. Conversely, we found minimal differences in the frequencies of the minor allele of SNP rs1205 (A) reported in other populations, which vary from 33 to $35 \%$. We also found this variation with the minor allele frequencies of rs2794521 (24.0 to 28.6\%; Kim et al., 2008; Kolz et al., 2008; Grammer et al., 2009). These differences can be explained by the genetic diversity among populations.

We found significant differences in the distribution of individuals carrying the genotypes of the SNPs rs1130864, rs1205, and rs2794521 throughout the strata of CRP in CHD risk. Evaluating the effect of the four SNPs on serum protein with co-dominant and dominant 
inheritance models clearly shows a significant trend in the increase in CRP across the genotypes of SNP rs1130864, a decreasing trend across the genotypes of SNP rs1205, and an additive effect in the dominant models. This trend was not observed with the rs 2794521 SNP. The effects of the SNPs on the variation in CRP levels have been reported in various populations around the world (Kolz et al., 2008; Almeida et al., 2009; Grammer et al., 2009; Schumacher et al., 2009; Teng et al., 2009; Mendoza-Carrera et al., 2010), demonstrating that the effect of $C R P$ SNPs on CRP occurs independent of ethnicity.

We found that individuals carrying the TT genotype of SNP rs1130864 displayed an increase in average BMI of $1.1 \mathrm{~kg} / \mathrm{m}^{2}$ compared with that in CC carriers. A genome scan study found 2 regions linked to T2D in chromosomes 1 and 6 (1q21-q24 and 6q21-q23; Xiang et al., 2004), which is the locus of $C R P$ on chromosome 1 (1q21-q23; http://www.genenames.org/ data/hgnc_data.php?hgnc_id=2367). In addition, an association among T2D and several CRP SNPs has been reported (Zee et al., 2008), suggesting that they may be candidate genes associated with T2D, a disease that is usually preceded by obesity or metabolic syndrome, disorders related to insulin resistance, and CVD. Meanwhile, Teng et al. (2009) reported an obesity-SNP interaction with increased serum levels of CRP and the SNPs rs2794521 and rs1800947 ( $\mathrm{P}=$ 0.034 and $\mathrm{P}=0.020$, respectively).

Several studies have found an association between various haplotypes of the gene and variation in CRP levels (Miller et al., 2005; Kathiresan et al., 2006; Teng et al., 2009). In our study, two haplotypes (TGAG, CGG) had a significant effect on serum CRP levels, a relationship not observed with BMI. This result indicates a clear effect of genetic variability on serum levels of CRP.

In conclusion, our results demonstrated the independent effect of variants in $C R P$ on protein levels as well as a possible relationship between the TT genotype of SNP rs1130864 and increased BMI. Future studies are needed to evaluate the relationship between $C R P$ variants and the presence of obesity.

\section{ACKNOWLEDGMENTS}

Research supported by the Integral Program for Institutional Strengthening of the Secretaría de Educación Pública de México. The authors declare no conflicts of interest.

\section{REFERENCES}

Almeida OP, Norman PE, Allcock R, van Bockxmeer F, et al. (2009). Polymorphisms of the CRP gene inhibit inflammatory response and increase susceptibility to depression: the Health in Men Study. Int. J. Epidemiol. 38: 1049-1059.

Black S, Kushner I and Samols D (2004). C-reactive protein. J. Biol. Chem. 279: 48487-48490.

Blake GJ and Ridker PM (2001). Novel clinical markers of vascular wall inflammation. Circ. Res. 89: 763-771.

Brull DJ, Serrano N, Zito F, Jones L, et al. (2003). Human CRP gene polymorphism influences CRP levels implications for the prediction and pathogenesis of coronary heart disease. Arterioscler. Thromb. Vasc. Biol. 23: -2063.

Carlson CS, Aldred SF, Lee PK, Tracy RP, et al. (2005). Polymorphisms within the C-reactive protein (CRP) promoter region are associated with plasma CRP levels. Am. J. Hum. Genet. 77: 64-77.

Chen J, Zhao J, Huang J, Su S, et al. (2005). -717A $>$ G polymorphism of human C-reactive protein gene associated with coronary heart disease in ethnic Han Chinese: the Beijing atherosclerosis study. J. Mol. Med. 83: 72-78.

Flores-Alfaro E, Parra-Rojas I, Salgado-Bernabe AB, Chavez-Maldonado JP, et al. (2008). Cardiovascular risk evaluated by C-reactive protein levels in diabetic and obese Mexican subjects. Circ. J. 72: 1170-1174.

Gelaye B, Revilla L, Lopez T, Suarez L, et al. (2010). Association between insulin resistance and c-reactive protein among Peruvian adults. Diabetol. Metab. Syndr. 2: 30. 
Grammer TB, Marz W, Renner W, Bohm BO, et al. (2009). C-reactive protein genotypes associated with circulating C-reactive protein but not with angiographic coronary artery disease: the LURIC study. Eur. Heart. J. 30: 170-182.

Hsu LA, Chang CJ, Wu S, Teng MS, et al. (2010). Association between functional variants of the ICAM1 and CRP genes and metabolic syndrome in Taiwanese subjects. Metabolism 59: 1710-1716.

Hu G, Jousilahti P, Tuomilehto J, Antikainen R, et al. (2009). Association of serum C-reactive protein level with sexspecific type 2 diabetes risk: a prospective finnish study. J. Clin. Endocrinol. Metab. 94: 2099-2105.

INAFED (2005). Enciclopedia de los Municipios de México, Jalisco. Government of Mexico. Website Instituto Nacional para el Federalismo y el Desarrollo Municipal. Available at [http:/www.inafed.gob.mx/wb/ELOCAL/EMM_ jalisco]. Accessed May 8, 2011.

Israelsson E, Ekstrom M, Nasr A, Dolo A, et al. (2009). Marked differences in CRP genotype frequencies between the Fulani and sympatric ethnic groups in Africa. Malar. J. 8: 136.

Kathiresan S, Larson MG, Vasan RS, Guo CY, et al. (2006). Contribution of clinical correlates and 13 C-reactive protein gene polymorphisms to interindividual variability in serum C-reactive protein level. Circulation 113: 1415-1423.

Kim IK, Ji F, Morrison MA, Adams S, et al. (2008). Comprehensive analysis of CRP, CFH Y402H and environmental risk factors on risk of neovascular age-related macular degeneration. Mol. Vis. 14: 1487-1495.

Kolz M, Koenig W, Muller M, Andreani M, et al. (2008). DNA variants, plasma levels and variability of C-reactive protein in myocardial infarction survivors: results from the AIRGENE study. Eur. Heart. J. 29: 1250-1258.

Komurcu-Bayrak E, Erginel-Unaltuna N, Onat A, Ozsait B, et al. (2009). Association of C-reactive protein (CRP) gene allelic variants with serum $C R P$ levels and hypertension in Turkish adults. Atherosclerosis 206: 474-479.

Kuhlenbaeumer G, Huge A, Berger K, Kessler C, et al. (2010). Genetic variants in the C-reactive protein gene are associated with microangiopathic ischemic stroke. Cerebrovasc. Dis. 30: 476-482.

Lai MM, Li CI, Kardia SL, Liu CS, et al. (2010). Sex difference in the association of metabolic syndrome with high sensitivity C-reactive protein in a Taiwanese population. BMC Public. Health 10: 429.

Lange LA, Carlson CS, Hindorff LA, Lange EM, et al. (2006). Association of polymorphisms in the CRP gene with circulating C-reactive protein levels and cardiovascular events. JAMA 296: 2703-2711.

Martinez-Fierro ML, Beuten J, Leach RJ, Parra EJ, et al. (2009). Ancestry informative markers and admixture proportions in northeastern Mexico. J. Hum. Genet. 54: 504-509.

Martinez-Marignac VL, Valladares A, Cameron E, Chan A, et al. (2007). Admixture in Mexico City: implications for admixture mapping of type 2 diabetes genetic risk factors. Hum. Genet. 120: 807-819.

Mendoza-Carrera F, Ramirez-Lopez G, Ayala-Martinez NA, Garcia-Zapien AG, et al. (2010). Influence of CRP, IL6, and TNFA gene polymorphisms on circulating levels of C-reactive protein in Mexican adolescents. Arch. Med. Res. 41: 472-477.

Miller DT, Zee RY, Suk DJ, Kozlowski P, et al. (2005). Association of common CRP gene variants with CRP levels and cardiovascular events. Ann. Hum. Genet. 69: 623-638.

Momiyama Y, Ohmori R, Fayad ZA, Kihara T, et al. (2010). Associations between plasma C-reactive protein levels and the severities of coronary and aortic atherosclerosis. J. Atheroscler. Thromb. 17: 460-467.

Oudi ME, Aouni Z, Mazigh C, Khochkar R, et al. (2010). Homocysteine and markers of inflammation in acute coronary syndrome. Exp. Clin. Cardiol. 15: e25-e28.

Pearson TA, Mensah GA, Alexander RW, Anderson JL, et al. (2003). Markers of inflammation and cardiovascular disease: application to clinical and public health practice: A statement for healthcare professionals from the Centers for Disease Control and Prevention and the American Heart Association. Circulation 107: 499-511.

Rizzello V, Liuzzo G, Giannuario GD, Trabetti E, et al. (2007). 1059G/C polymorphism within the exon 2 of the C-reactive protein gene: relationship to C-reactive protein levels and prognosis in unstable angina. Coron. Artery Dis. 18: 533-538.

Russell AI, Cunninghame Graham DS, Shepherd C, Roberton CA, et al. (2004). Polymorphism at the C-reactive protein locus influences gene expression and predisposes to systemic lupus erythematosus. Hum. Mol. Genet. 13: 137-147.

Sabatine MS, Morrow DA, Jablonski KA, Rice MM, et al. (2007). Prognostic significance of the Centers for Disease Control/American Heart Association high-sensitivity C-reactive protein cut points for cardiovascular and other outcomes in patients with stable coronary artery disease. Circulation 115: 1528-1536.

Sanchez-Recalde A and Carlos KJ (2001). Diabetes mellitus, inflammation and coronary atherosclerosis: current and future perspectives. Rev. Esp. Cardiol. 54: 751-763.

Schumacher W, Cockcroft J, Timpson NJ, McEniery CM, et al. (2009). Association between C-reactive protein genotype, circulating levels, and aortic pulse wave velocity. Hypertension 53: 150-157.

Shankar A and Li J (2008). Positive association between high-sensitivity C-reactive protein level and diabetes mellitus among US non-Hispanic black adults. Exp. Clin. Endocrinol. Diabetes 116: 455-460.

Silva-Zolezzi I, Hidalgo-Miranda A, Estrada-Gil J, Fernandez-Lopez JC, et al. (2009). Analysis of genomic diversity in Mexican Mestizo populations to develop genomic medicine in Mexico. Proc. Natl. Acad. Sci. U. S. A. 106: 8611-8616.

Szalai AJ, Wu J, Lange EM, McCrory MA, et al. (2005). Single-nucleotide polymorphisms in the C-reactive protein $(C R P)$

Genetics and Molecular Research 11 (3): 2258-2267 (2012)

CFUNPEC-RP www.funpecrp.com.br 
gene promoter that affect transcription factor binding, alter transcriptional activity, and associate with differences in baseline serum CRP level. J. Mol. Med. 83: 440-447.

Teng MS, Hsu LA, Wu S, Chang HH, et al. (2009). Association between C-reactive protein gene haplotypes and C-reactive protein levels in Taiwanese: interaction with obesity. Atherosclerosis 204: e64-e69.

Tsai AC and Tsai HJ (2010). The association of age, gender, body fatness and lifestyle factors with plasma C-reactive protein concentrations in older Taiwanese. J. Nutr. Health Aging 14: 412-416.

Wee CC, Mukamal KJ, Huang A, Davis RB, et al. (2008). Obesity and C-reactive protein levels among white, black, and hispanic US adults. Obesity (Silver Spring) 16: 875-880.

Xiang K, Wang Y, Zheng T, Jia W, et al. (2004). Genome-wide search for type 2 diabetes/impaired glucose homeostasis susceptibility genes in the Chinese: significant linkage to chromosome 6q21-q23 and chromosome 1q21-q24. Diabetes 53: 228-234.

Zee RY, Germer S, Thomas A, Raji A, et al. (2008). C-reactive protein gene variation and type 2 diabetes mellitus: a casecontrol study. Atherosclerosis 197: 931-936. 